\title{
PENGARUH STRATEGI PEMBELAJARAN DAN MOTIVASI BELAJAR SISWA TERHADAP HASIL BELAJAR MEMAHAMI BAHAN BANGUNAN PADA SISWA KELAS X PROGRAM KEAHLIAN TEKNIK GAMBAR BANGUNAN SMK NEGERI 2 MEDAN
}

\author{
Herti N S Situmeang ${ }^{1}$, Abdul Hamid ${ }^{2}$ \\ ${ }^{1}$ Alumni Program Studi Pendidikan Teknik Bangunan, Fakultas Teknik UNIMED \\ ${ }^{2}$ Dosen Pengajar Jurusan Pendidikan Teknik Bangunan, Fakultas Teknik UNIMED \\ (abdulhamid@gmail.com)
}

\begin{abstract}
ABSTRAK
Penelitian ini bertujuan untuk mengetahui pengaruh strategi pembelajaran Think Pair Share dan strategi pembelajaran Student Team Achievment Devision dengan melihat karakteristik motivasi belajar siswa dalam pembelajaran. Subjek penelitian ini adalah siswa kelas X Teknik Gambar Bangunan dengan jumlah 62 orang yang terdiri dari kelas X Teknik Gambar Bangunan 1 untuk perlakuan dengan Strategi Pembelajaran Student Team Achievment Devision sebanyak 32 orang dan kelas X Teknik Gambar Bangunan 2 untuk perlakuan dengan Strategi Pembelajaran Think Pair Share sebanyak 30 orang.

Sebelum penelitian ini dilakukan instrument penelitian terlebih dahulu di uji cobakan, dilanjutkan dengan uji validitas dan uji reabilitas. Uji validitas butir tes digunakan rumus korelasi biserial. Uji reliabislitas tes digunakan rumus KR-20. Teknik pengumpulan data hasil belajar dengan menggunakan rancangan penelitian menggunakan desain Anava $2 \times 2$. Variabel penelitian memenuhi persyaratan normalitas diuji dengan uji Liliefors dan homogenitas diuji dengan uji $F$ dan uji Barlett.

Dari hasil pengujian menunjukkan bahwa: (1) hasil belajar Memahami Bahan Bangunan siswa yang diajar dengan Startegi Pembelajaran Think pair Share lebih tinggi dari hasil belajar siswa yang diajar dengan Strategi Pembelajaran Student Team Achievment Devision dengan ditunjukkan $F_{\text {hitung }}=23.98>F_{\text {tabel }}=4.01$ pada taraf signifikansi $a=0.05$. (2) sedangkan hasil belajar siswa yang memiliki motivasi tinggi lebih tinggi dari hasil belajar siswa yang memiliki motivasi belajar rendah, dengan ditunjukkan $F_{\text {hitung }}=7.44>F_{\text {tabel }}=4.01$. (3) Terdapat interaksi antara strategi pembelajaran dan motivasi belajar terhadap hasil belajar Memahami bahan Bangunan, hal ini ditunjukkan diperolehnya $F_{\text {hitung }}=69.38>F_{\text {tabel }}=4.01$ pada taraf signifikansi $5 \%$.
\end{abstract}

Kata Kunci : Pembelajaran Berbasis Masalah, Keaktifan, Hasil Belajar

\begin{abstract}
This study aims to determine the effect of Think Pair Share instructional strategies and learning strategies Student Team Achievement devision by looking at the characteristics of students' motivation in learning. The subjects were students of class X Architecture Engineering with the number of 62 people consisting of class X Architecture Engineering 1 to treatment with Learning Strategies Student Team Achievement Devision 32 people and class X Architecture Engineering 2 for treatment with Learning Strategy Think Pair Share as many as 30 people.

Prior to this research, the research instrument first be tested, followed by validity and reliability test. Test the validity of the test used biserial correlation formula. Test reliabislitas test used formula KR-20. Learning outcomes data collection techniques using research design using design Anava $2 \times 2$. Variables meet the requirements tested with Liliefors normality and homogeneity were tested by F test and test Barlett.

From the test results showed that: (1) the learning outcomes Understanding Building Materials students who are taught by Strategy Learning Think pair Share is higher than the learning outcomes of students who are taught by Learning Strategies Student Team Achievement devision with demonstrated Fhitung $=23.98>$ F table $=4.01$ The extent of significance $a=0: 05$. (2) while the learning outcomes of students who have high motivation
\end{abstract}


is higher than student learning outcomes that have a low learning motivation, with demonstrated Fhitung = 7:44> Ftabel $=4: 01$. (3) There is an interaction between learning strategies and motivation toward learning outcomes Understanding Building materials, it is shown obtaining Fhitung $=69.38>\mathrm{F}$ table $=4: 01$ to $5 \%$ significance level.

\section{Keywords: Problem Based Learning, activity and Learning Outcomes}

\section{Pendahuluan}

Pendidikan dipandang sebagai sesuatu yang penting untuk meningkatkan harkat dan martabat suatu bangsa dan untuk meningkatkan kemajuan suatu bangsa yang lebih baik dari sebelumnya. Peningkatan mutu pendidikan banyak dicanangkan oleh setiap negara untuk memajukan negaranya. Keberhasilan dan kegagalan pendidikan suatu negara mempunyai pengaruh yang sangat signifikan bagi perkembangan kualitas generasi yang akan datang.

Salah satu lembaga pendidikan formal yang diharapkan mampu melaksanakan tujuan pendidikan nasional adalah Sekolah Menengah Kejuruan (SMK), yang menghasilkan siswa yang terampil, cakap, serta siap bekerja dalam dunia usaha.

SMK sebagai lembaga yang memiliki bidang keahlian yang berbeda-beda menyesuaikan dengan lapangan kerja yang ada. Di SMK para siswa dididik dan dilatih keterampilan agar profesional dalam bidang keahliannya masingmasing. Sesuai dengan Kurikulum Spektrum Sekolah Menengah Kejuruan (2008), SMK memiliki tujuan untuk : 1) menyiapkan peserta didik agar menjadi manusia produktif, mampu bekerja mandiri, mengisi lowongan pekerjaan yang ada di dunia usaha dan dunia industri sebagai tenaga kerja tingkat menengah sesuai dengan kompetisi dalam program keahlian yang dipilihnya, 2) menyiapkan peserta didik agar mampu memilih karir, ulet dan gigih dalam berkompetensi, beradaptasi di lingkungan kerja, dan mengembangkan sikap profesional dalam bidang keahlian yang diminatinya, 3) membekali peserta didik dengan ilmu pengetahuan, teknologi dan seni, agar mampu mengembangkan diri di kemudian hari baik secara mandiri maupun melalui jenjang pendidikan yang lebih tinggi, 4) membekali peserta didik dengan kompetensikompetensi yang sesuai dengan program keahlian yang dipilihnya.

Prestasi belajar yang dicapai oleh siswa dapat dipengaruhi oleh beberapa faktor, baik yang berasal dari diri siswa (faktor internal) maupun dari luar siswa (faktor eksternal). Faktor internal diantaranya ialah minat, bakat, motivasi , tingkat intelegensi. Sedangkan factor eksternal diantaranya adalah strategi pembelajaran dan lingkungan belajar siswa. Untuk mencapai hal tersebut maka dibutuhkan pembelajaran yang tepat dan efektif untuk siswa SMK yang sesuai dengan kurikulum dan mengaitkan materi yang diajarkan guru dengan penerapan yang tepat dalam kehidupan masyarakat umumnya dan masyarakat sekitar siswa khususnya.

Dari hasil observasi yang dilakukan penulis ke sekolah SMK Negeri 2 Medan dengan guru mata pelajaran bahwa hasil belajar untuk Memahami Bahan Bangunan siswa kelas X Program Keahlian Teknik Gambar Bangunan Tahun Ajaran 2013/2014 pada semester ganjil.

Tabel 1 Daftar Kumpulan Nilai TA.2013/2014 Mata Pelajaran Memahai Bahan Bangunan Kelas X SMKN 2 Medan

\begin{tabular}{|c|c|c|c|c|}
\hline TA & $\begin{array}{c}\text { Interval } \\
\text { Kelas }\end{array}$ & $\begin{array}{l}\text { JLH } \\
\text { Sis } \\
\text { wa }\end{array}$ & $\%$ tase & Ket \\
\hline \multirow{5}{*}{$\begin{array}{r}2013 / \\
2014\end{array}$} & $\leq 74$ & 21 & $60 \%$ & $\begin{array}{c}\text { Tidak } \\
\text { Kompeten }\end{array}$ \\
\hline & $75-84$ & 7 & $20 \%$ & $\begin{array}{l}\text { Cukup } \\
\text { Kompeten }\end{array}$ \\
\hline & $85-94$ & 5 & $14.3 \%$ & Kompeten \\
\hline & \multirow[t]{2}{*}{$95-100$} & 2 & $5.7 \%$ & \multirow[t]{2}{*}{$\begin{array}{l}\text { Sangat } \\
\text { Kompeten }\end{array}$} \\
\hline & & 35 & $100 \%$ & \\
\hline
\end{tabular}

(Sumber: SMKN 2 Medan)

\section{Kajian Teori}

2.1 Hakikat Hasil Belajar Memahami Bahan Bangunan

Seseorang dikatakan belajar, apabila terjadi perubahan prilaku tertentu seperti dari tidak tahu menjadi tahu, dari tidak dapat menjadi dapat perubahan tersebut akan nyata 


\section{Pengaruh Strategi Pembelajaran dan Motivasi Belajar Siswa Terhadap Hasil Belajar Memahami Bahan Bagunan Pada siswa kelas X Program Keahlian Tenik Gambar Bangunan SMK Negeri 2 Medan}

dalam seluruh aspek tingkah laku. Belajar juga merupakan proses dalam diri individu yang berinteraksi dengan lingkungan untuk mendapatkan perubahan dalam perilakunya. Gagne (Slameto, 2003:13) menyebutkan belajar ialah suatu proses untuk memperoleh motivasi dalam pengetahuan, keterampilan, kebiasaan dan tingkah laku.

Menurut Nana Sudjana (2009:3) hasil belajar pada dasarnya merupakan akibat dari suatu proses belajar, hal ini berarti optimalnya hasil belajar seseorang akan mengalami perubahan dalam tingkah lakunya. Perubahan dalam tingkah laku yang terjadi dalam diri seseorang melalui belajar disebut hasil belajar.

Pada penelitian ini hasil belajar yang ingin diteliti adalah hasil belajar Memahami Bahan Bangunan yang merupakan salah satu kompetensi kejuruan dalam program produktif yang harus dikuasai oleh siswa SMK program keahlian Teknik Gambar Bangunan. Memahami Bahan Bangunan ini memiliki beberapa kompetensi dasar yaitu mendeskripsikan bahan bangunan kayu, mendeskripsikan bahan bangunan batu dan beton dan mendeskripsikan bahan bangunan baja. Jadi hasil belajar Memahami Bahan Bangunan adalah bentuk penguasaan dalam wujud perilaku kognitif yang diperoleh akibat adanya suatu proses belajar dalam materi Memahami Bahan Bangunan.

\subsection{Hakekat Pembelajaran Kooperatif}

Pembelajaran kooperatif adalah pembelajaran dalam motif kerja sama, dimana setiap individu dihadapkan pada pilihan yang harus diikuti, apakah memilih bekerja sama, kompetisi, atau individual.

Menurut Roger dan Johson (dalam Lie, 2010:31), bahwa tidak semua kerja kelompok bisa dianggap pembelajaran kooperatif sehingga untuk mencapai hasil yang maksimal perlu diterapkan lima unsur strategi pembelajaran kooperatif, yaitu:

a. Saling ketergantungan positif, artinya keberhasilan kelompok sangat dipengaruhi oleh usaha setiap anggotanya.

b. Tanggung jawab perseorangan, artinya setiap anggota kelompok harus melaksanakan tugasnya dengan baik untuk keberhasilan kelompok.

c. Tatap muka, artinya setiap kelompok harus diberikan kesempatan untuk bertemu dan berdiskusi. Kegiatan interaksi ini akan mendorong siswa untuk membentuk sinergi yang menguntungkan semua anggota kelompoknya.

d. Komunikasi antar anggota, unsur ini menghendaki agar siswa dibekali dengan berbagai ketrampilan berkomunikasi,

e. Evaluasi proses kelompok, guru perlu menjadwalkan waktu khusus bagi kelompok untuk mengevaluasi proses kerja kelompok dan hasil kerja sama mereka agar selanjutnya bisa bekerja sama secara efektif.

Pembelajaran kooperatif bernaung dalam teori konstruktivis. Pembelajaran ini muncul dari konsep bahwa siswa akan lebih mudah menemukan dan memahami konsep yang sulit jika mereka saling berdiskusi dengan temannya. Siswa secara rutin bekerja dalam kelompok untuk saling membantu memecahkan masalah-masalah yang kompleks. Jadi hakikat sosial dan penggunaan kelompok menjadi aspek utama pembelajaran kooperatif. Dan pada strategi pembelajaran kooperatif siswalah yang lebih aktif dalam kegiatan belajar sedangkan guru adalah pengelola aktivitas kelompok.

Tabel 2. Langkah-Langkah Pembelajaran Kooperatif

\begin{tabular}{|c|c|}
\hline Fase & Tingkah Laku Guru \\
\hline $\begin{array}{l}\text { Fase } 1 \\
\text { Menyampaikan } \\
\text { tujuan dan } \\
\text { memotivasi } \\
\text { siswa }\end{array}$ & $\begin{array}{l}\text { Guru menyampaikan } \\
\text { semua tujuan pembelajaran } \\
\text { yang ingin dicapai pada } \\
\text { pelajaran tersebut dan } \\
\text { memotivasi siswa belajar }\end{array}$ \\
\hline $\begin{array}{l}\text { Fase } 2 \\
\text { Menyajikan } \\
\text { informasi }\end{array}$ & $\begin{array}{l}\text { Guru menyajikan informasi } \\
\text { kepada siswa dengan } \\
\text { demonstrasi atau buat } \\
\text { bacaan }\end{array}$ \\
\hline $\begin{array}{l}\text { Fase } 3 \\
\text { Mengorganisasi } \\
\text { kan siswa } \\
\text { kedalam kelom } \\
\text { pok-kelompok } \\
\text { belajar }\end{array}$ & $\begin{array}{l}\text { Guru menjelaskan kepada } \\
\text { siswa bagaimana caranya } \\
\text { membentuk kelompok } \\
\text { belajar dan membantu } \\
\text { setiap kelompok agar } \\
\text { melakukan transisi secara } \\
\text { efisien }\end{array}$ \\
\hline $\begin{array}{l}\text { Fase } 4 \\
\text { Membimbing ke } \\
\text { lompok bekerja } \\
\text { dan belajar }\end{array}$ & $\begin{array}{l}\text { Guru membimbing } \\
\text { kelompok-kelompok } \\
\text { belajar pada saat mereka } \\
\text { mengerjakan tugas mereka }\end{array}$ \\
\hline $\begin{array}{l}\text { Fase } 5 \\
\text { Evaluasi }\end{array}$ & $\begin{array}{l}\text { Guru mengevaluasi hasil } \\
\text { belajara siswa tentang } \\
\text { materi yang telah dipelajari } \\
\text { atau masing-masing } \\
\text { kelompok } \\
\text { mempersentasikan hasil }\end{array}$ \\
\hline
\end{tabular}




\begin{tabular}{ll}
\hline & kerjanya. \\
\hline Fase 6 & Guru mencari cara untuk \\
Memberikan & menghargai baik upaya \\
penghargaan & $\begin{array}{l}\text { maupun hasil belajar } \\
\text { individu dan kelompok. }\end{array}$ \\
\hline
\end{tabular}

(Sumber : Ibrahim dkk, dalam Trianto (2009:66-67)

Trianto (2007:67) terdapat beberapa varians dari model tersebut. Terdapat empat pendekatan yang seharusnya merupakan bagian dari kumpulan strategi guru dalam menerapkan model pembelajaran kooperatif, digolongkan dalam beberapa jenis yaitu Students Team Achievemen Division (STAD), Jigsaw; Insvestigasi Kelompok TGT (Teams Games Tournamen) dan Pendekatan Struktural NHT (Number Heads Together) dan Think pair share (TPS).

\subsubsection{Strategi Pembelajaran Kooperatif Tipe TPS}

Menurut (Trianto, 2009:81) Langkahlangkah (fase) yang diterapkan dalam Think Pair Share adalah sebagai berikut:

Langkah 1: Think (berfikir). Guru mengajukan pertanyaan atau isu yang berhubungan dengan pelajaran. Kemudian siswa diminta untuk memikirkan jawaban pertanyaan tersebut secara mandiri untuk beberapa saat.

Langkah 2: Pairing (berpasangan). Guru meminta siswa berpasangan dengan siswa yang lain untuk mendiskusikan apa yang telah dipikirkan pada tahap pertama. Interaksi pada periode ini dapat menghasilkan jawaban bersama jika pertanyaan telah diajukan atau penyampaian ide bersama jika isu khusus telah diidentifikasi. Biasanya guru mengijinkan tidak lebih dari 4 atau 5 menit untuk berpasangan.

Langkah 3: Sharing (berbagi). Pada tahap akhir, guru meminta pasangan-pasangan tersebut untuk berbagi atau bekerja sama dengan kelas secara keseluruhan mengenai yang telah mereka bicarakan. Langkah ini efektif jika guru berkeliling kelas dari pasangan yang satu kepasangan yang lain, sehingga seperempat atau separuh dari pasanganpasangan tersebut memperoleh kesempatan untuk melaporkan.

Think Pair Share digunakan untuk mengecek pemahaman siswa terhadap isi tertentu. Guru menciptakan interaksi yang dapat mendorong rasa ingin tahu, ingin mencoba, bersikap mandiri, dan ingin maju. Guru memberi imformasi, hanya informasi yang mendasar saja, sebagai dasar bagi anak didik dalam mencari dan menemukan sendiri informasi lainnya. Guru menjelaskan materi dengan mengaitkannya dengan pengalaman dan pengetahuan anak sehingga memudahkan mereka menanggapi dan memahami pengalaman yang baru bahkan membuat anak didik mudah memusatkan perhatian. Karna guru sangat perlu memperhatikan pengalaman dan pengetahun anak didik yang didapatinya dalam kehidupan sehari-hari.

Tabel 3. Sintaks Think Pair Share

Tahap Kegiatan Guru

\begin{tabular}{llr}
\hline 1. Menyampa & Menyampaikan & salam, \\
ikan tujuan & memotivasi & siswa, \\
dan & menjelaskan & tujuan \\
mengatur & pembelajaran & \\
siswa & & \\
\hline
\end{tabular}

$\begin{array}{cl}\text { 2. Mengarahk } & \begin{array}{l}\text { Mengajukan } \\ \text { an diskusi }\end{array} \\ \text { awal } & \end{array}$

a. Membimbing/mengarahka n siswa dalam mengerjakan LKS secara mandiri (Think)

b. Membimbing/meng

3. Menyeleng arahkan siswa dalam garakan berpasangan (Pair)

diskusi c. Membimbing/mengarahka $\mathrm{n}$ siswa dalam berbagi (Share)

d.Menerapkan waktu tunggu

e. Membimbing kegiatan siswa

\begin{tabular}{ll}
\hline 4. $\begin{array}{l}\text { Mengakhir } \\
\text { i diskusi }\end{array}$ & Menutup diskusi \\
\hline 5. $\begin{array}{l}\text { Melakukan } \\
\text { tanya }\end{array}$ & \\
jawab & Membantu siswa membuat \\
singkat & rangkuman diskusi dengan \\
tentang & tanya jawab singkat \\
diskusi & \\
\hline
\end{tabular}

(Sumber : Tjokrodiharjo dalam Trianto 2009:124)

\subsubsection{Strategi Pembelajaran kooperatif tipe STAD \\ Student Team Achievement Division (STAD) merupakan tipe pembelajaran}




\section{Pengaruh Strategi Pembelajaran dan Motivasi Belajar Siswa Terhadap Hasil Belajar Memahami Bahan Bagunan Pada siswa kelas X Program Keahlian Tenik Gambar Bangunan SMK Negeri 2 Medan}

kooperatif yang dikembangkan oleh Robert Slavin dan teman-temannya di Universitas John Hopkin. Tipe ini merupakan salah satu tipe pembelajaran kooperatif yang paling sederhana dan sebuah strategi yang bagus untuk memulai bagi seorang guru yang baru untuk menggunakan pendekatan kooperatif.

Menurut Sanjaya (2006: 248) strategi pembelajaran STAD terdiri dari empat tahap yaitu:

a. Penjelasan materi

Diartikan sebagai proses penyampaian pokok-pokok materi pelajaran sebelum siswa belajar dalam kelompok. Tujuan utama dalam tahapan ini adalah pemahaman siswa terhadap pokok materi pelajaran. Pada tahapan ini guru menggunakan metode ceramah, curah pendapat dan tanya jawab serta menggunakan demonstrasi.

b. Belajar dalam kelompok

Siswa dibagi dalam beberapa kelompok 4 atau 5 orang dalam satu kelompok. Kelompok ini dapat dibagi secara homegen dan heterogen. Baik berdasarkan ras, jenis kelamin, agama, dan prestasi.

c. Penilaian

Penilian dapat dilakukan dengan menggunakan tes dan kuis dan dilakukan baik secara individual maupun kelompok. Hasil akhir setiap siswa adalah penggabungan keduanya dan dibagi dua. Nilai setiap individu memiliki nilai bersama dalam kelompoknya. Hal ini disebabkan nilai kelompok adalah nilai bersama dalam kelompoknya yang merupakan hasil kerja sama setiap anggota kelompok.

d. Pengakuan tim

Adalah penetapan tim yang dianggap paling menonjol atau tim yang paling berprestasi untuk kemudian diberikan penghargaan atau hadiah.

Langkah-langkah pembelajaran STAD ini didasarkan pada langkah-langkah pembelajaran kooperatif yang terdiri atas enam fase. Fase-fase dalam pembelajran ini dapat dilihat pada tabel berikut:

Tabel 4. Sintaks Student Team Achievement Division

Fase Kegiatan guru

\begin{tabular}{|c|c|c|}
\hline 1. & $\begin{array}{l}\text { Menyampa } \\
\text { ikan tujuan } \\
\text { dan } \\
\text { motivasi } \\
\text { siswa }\end{array}$ & $\begin{array}{l}\text { Menyampaikan semua } \\
\text { tujuan pembelajaran } \\
\text { yang ingin dicapai pada } \\
\text { pelajaran tersebut dan } \\
\text { memotivasi siswa } \\
\text { belajar }\end{array}$ \\
\hline 2. & $\begin{array}{l}\text { Menyajika } \\
\mathrm{n} / \\
\text { menyampi } \\
\text { kan } \\
\text { informasi }\end{array}$ & $\begin{array}{l}\text { Menyajikan informasi } \\
\text { kepada siswa dengan } \\
\text { jalan } \\
\text { mendemonstrasikan } \\
\text { atau lewat bacaan }\end{array}$ \\
\hline 3. & $\begin{array}{l}\text { Mengorga } \\
\text { nisasikan } \\
\text { siswa keda } \\
\text { lam } \\
\text { kelompok- } \\
\text { kelompok } \\
\text { belajar }\end{array}$ & $\begin{array}{lr}\text { Menjelaskan } & \text { kepada } \\
\text { siswa } & \text { bagaimana } \\
\text { membentuk kelompok } \\
\text { belajar dan membantu } \\
\text { setiap kelompok agar } \\
\text { melakukan transisi } \\
\text { secara efisien }\end{array}$ \\
\hline 4. & $\begin{array}{l}\text { Membimbi } \\
\text { ng } \\
\text { kelompok } \\
\text { bekerja } \\
\text { dan belajar }\end{array}$ & $\begin{array}{l}\text { Membimbing kelompok } \\
\text { - kelompok belajar pada } \\
\text { saat mereka } \\
\text { mengerjakan tugas }\end{array}$ \\
\hline 5. & Evaluasi & $\begin{array}{l}\text { Mengevaluasi hasil } \\
\text { belajar tentang materi } \\
\text { yang telah dipelajari }\end{array}$ \\
\hline
\end{tabular}

\subsection{Hakekat Motivasi belajar}

Hakekat motivasi belajar adalah dorongan internal dan eksternal pada diri siswa yang sedang belajar untuk mengadakan perubahan tingkah laku, pada umumnya dengan beberapa indikator atau unsur yang mendukung.

Motivasi dapat diartikan sebagai suatu usaha yang ada dalam diri individu yang berupa sikap, tindakan dan dorongan untuk bertindak dalam mengarahkan serta menggerakkan individu pada suatu tingkah laku sehingga tujuan yang dikehendaki dapat tercapai. Dalam kaitannya dengan belajar, motivasi sangat erat hubungannya dengan kebutuhan aktualisasi diri sehingga motivasi paling besar pengaruhnya pada kegiatan belajar siswa yang bertujuan untuk mencapai prestasi tinggi.

Sifat motivasi dibagi atas dua golongan yaitu:

a. Motivasi intrinsik adalah motif-motif yang menjadi aktif atau berfungsinya tidak perlu dirangsang dari luar, karena dalam diri setiap individu suatu dorongan untuk melakukan sesuatu (Sardiman A.M, 2003:89).Dorongan tersebut bersumber pada 
suatu kebutuhan yaitu kebutuhan yang berisikan keharusan untuk menjadi orang yang terdidik.

b. Motivasi ekstrinsik adalah motif-motif yang aktif dan berfungsi karena adanya perangsang dari luar (Sardiman A.M, 2003:90). Motivasi ekstrinsik merupakan bentuk motivasi yang didalamnya aktivitas belajar dimulai dan diteruskan berdasarkan dorongan dari luar yang tidak secara mutlak berkaitan dengan aktivitas belajar.

Pada dasarnya motivasi adalah suatu usaha yang disadari untuk menggerakkan, mengarahkan dan menjaga tingkah laku seseorang agar ia terdorong untuk bertindak melakukan sesuatu sehingga mencapai hasil atau tujuan tertentu. Motivasi belajar adalah sesuatu perubahan tenaga didalam diri seseorang (pribadi) yang ditandai dengan timbulnya perasaan dan interaksi untuk mencapai tujuan.

\section{Kerangka Berfikir}

3.1 Pengaruh Strategi Pembelajaran TPS Dan Strategi Pembelajaran STAD Terhadap Hasil Belajar Memahami Bahan Bangunan

Strategi pembelajaran kooperatif TPS, siswa diberikan kesempatan untuk berfikir dan merespon dan saling membantu yang lain, dalam TPS terlebih dahulu guru memberikan informasi singkat materi pelajaran kemudian guru memberikan stimulus berupa pertanyaan atau lembar kerja siswa berkaitan dengan materi pelajaran tersebut. Siswa diberi kesempatan untuk merespon dengan informasi dan pengetahuannya, kemudian dipertemukan dalam satu kelompok heterogen yang tentu saja memiliki informasi dan pengetahuan yang berbeda Selanjutnya mereka diminta merespon stimulus yang diberikan guru sebagai satu kelompok, dimana diharapkan terjadi saling berbagi informasi antara siswa untuk memecahkan masalah yang dihadapi. Dan akhir kegiatan belajar, beberapa siswa dari kelompok diminta menyajikan hasil diskusi mereka didepan kelas dan siswa lain bertugas menjadi pembanding maka terciptalah diskusi dengan kelompok yang lebih besar.

Sementara pembelajaran STAD adalah siswa bekerja sama dalam kelompok untuk memecahkan masalah yang dihadapi atau setelah mempelajari materi pelajaran yang diberikan, masing-masing individu diberi kuis untuk mengetahui sejauh mana penguasaan siswa terhadap materi yang diberikan. Masingmasing nilai siswa akan digabungkan dan dicari rata-rata untuk menentukan nilai kelompok. Kelompok yang memiliki nilai ratarata tertinggi menjadi kelompok yang terbaik diantar kelompok-kelompok yang ada. Peranan strategi pembelajaran STAD ini siswa dikelompokkan menjadi kelompok-kelompok yang mempertimbangkan heterogenistas seperti jenis kelamin, latar belakang sosia, dan lain sebagainya untuk menuntaskan materi pembelajarannya dan kemudian saling membantu satu sama lain untuk memahami bahan pelajaran. Staretgi pembelajaran STAD ini juga mengembangkan serta menggunakan keterampilan berfikir kritis siswa untuk bekerja sama dalam kelompok serta membantu siswa menyuburkan hubungan antar pribadi yang positif diantara siswa yang berasal dari RAS yang berbeda. Berdasarkan uraian diatas, maka dapat dugaan sementara bahwa terdapat perbedaan hasil belajar siswa yang diajar dengan TPS dan yang diajar dengan STAD.

\subsection{Pengaruh Motivasi Belajar Terhadap Hasil Belajar Memahami Bahan Bangunan \\ Teori belajar menyimpulkan bahwa} motivasi adalah salah satu indikator untuk mencapai hasil belajar. Dengan motivasi seseorang akan belajar dengan sungguhsungguh, dengan motivasi seseorang akan berusaha mencari buku-buku atau sumbersumber lain yang berkaitan dengan Memahami Bahan Bangunan. Siswa yang memiliki motivasi belajar yang rendah takut dalam kompetisi belajar, sehingga siswa tersebut akan mengalami kejenuhan belajar dan siswa tersebut tidak mau peduli lagi dengan apa yang dijelaskan atau yang diterangkan guru.

Hasil belajar memahami bahan bangunan merupakan tingkat penguasaan siswa terhadap materi yang yang diberikan dinyatakan dalam angka atau skor yang diperoleh dari tes. Skor yang diperoleh siswa berbeda-beda satu sama lain yakni ada yang mendapat rendah, sedang, tinggi sesuai dengan tingkat penguasaanya masing-masing.

Dari hal diatas dapat diduga bahwa siswa yang memiliki motivasi belajar tinggi akan mendapatkan hasil belajar yang lebih baik dari pada siswa yang memiliki motivasi belajar rendah pada pelajaran Memahami Bahan Bangunan. 


\section{Pengaruh Strategi Pembelajaran dan Motivasi Belajar Siswa Terhadap Hasil Belajar Memahami Bahan Bagunan Pada siswa kelas X Program Keahlian Tenik Gambar Bangunan SMK Negeri 2 Medan}

3.3 Interaksi Antara Strategi Pembelajaran dan Motivasi Belajar terhadap Hasil belajar Memahami Bahan Bangunan

Strategi pembelajaran TPS melibatkan siswa sepenuhnya dalam proses pembelajara untuk mencapai hasil belajar. Siswa dilatih untuk bertukar pendapat antara pemikirannya sendiri dengan temanya untuk mendapatkaan kesempatan dalam memecahkan masalah, untuk dapat belajar secara maksimal maka siswa harus lebih aktif dalam mengikuti pembelajaran dan merima informasi yang diberikan. Dengan demikian siswa yang memiliki motivasi belajar tinggi akan menjadi lebih aktif dan keinginan belajarnya akan terpenuhi. Strategi pembelajaran TPS melibatkan seluruh siswa dalam proses pembelajaran. Oleh karena itu seluruh siswa dalam kelas akan dibimbing agar dapat berpikir logis untuk menemukan jawaban dari pembelajaran yang sedang dihadapinya dan mendiskusikan apa yang telah dipikirkannya dengan berpasangan. Sehingga siswa yang memiliki motivasi rendah akan ambil bagian dalam proses pembelajaran yang dilakukan.

Strategi pembelajaran STAD melibatkan siswa dalam proses pembelajaran dalam bentuk kelompok, strategi pembelajaran ini mengembangkan siswa untuk berfikir kritis dalam bekerja sama didalam kelompok pembelajaran, sehingga siswa dapat mengkontruksikan pengetahuannya dalam kehidupnnya sehari-hari. Dalam hal ini, siswa yang aktif dalam proses kegiatan belajar mengajar cenderung memiliki motivasi belajar yang tinggi.

Berdasarkan penjelasan diatas, bahwa dengan menerapkan strategi pembelajaran TPS dan STAD dalam kegiatan belajar mengajar Memahami Bahan Bangunan siswa yang memiliki motivasi belajar yang tinggi akan memperoleh hasil belajar yang tinggi, sedangkan bagi siswa yang mempunyai motivasi belajar rendah, lebih banyak membutuhkan bimbingan dan arahan dari guru. Maka dapat diduga bahwa terdapat interaksi antara strategi pembelajaran dan motivasi belajar terhadap hasil belajar Memahami Bahan Bangunan.

\subsection{Hipotesis Penelitian}

Untuk melihat perbedaan hasil belajar siswa yang diajar dengan strategi pembelajaran TPS dan strategi pembelajaran STAD serta Motivasi Belajar diajukan hipotesis sebagai berikut: a. Strategi pembelajaran TPS lebih baik dari Strategi pembelajaran STAD terhadap hasil belajar Memahami Bahan Bangunan pada siswa kelas X Program Keahlian Teknik Gambar Bangunan SMK N 2 Medan

b. Motivasi belajar memberi pengaruh yang berbeda secara signifikan terhadap hasil belajar Memahami Bahan Bangunan pada siswa kelas X Program Keahlian Teknik Gambar Bangunan SMK N 2 Medan

c. Terdapat interaksi antara strategi pembelajaran dengan motivasi belajar siswa terhadap hasil belajar Memahami Bahan Bangunan pada siswa kelas $X$ program Keahlian Teknik Gambar Bangunan SMK N 2 Medan.

\subsection{Teknik Pengumpul Data}

\subsubsection{Angket Motivasi Belajar}

Untuk mengumpulkan data motivasi belajar dilakukan dengan angket. Instrumen yang disusun oleh peneliti dirumuskan kedalam bentuk defenisi operasional yang kemudian dijabarkan dalam bentuk kisi-kisi dibuat menjadi butir-butir soal/item. Adapun indikator instrument motivasi belajar dapat dilihat pada tabel 3.4. dibawah ini:

Tabel 5. Kisi-kisi Angket Motivasi Belajar

\begin{tabular}{|c|c|c|c|}
\hline No & Indikator & $\begin{array}{l}\text { Butir } \\
\text { Soal }\end{array}$ & JLH \\
\hline 1. & $\begin{array}{l}\text { Keseriusan dan } \\
\text { Ketekunan } \\
\text { dalam belajar }\end{array}$ & $\begin{array}{r}1,4,6,8,11 \\
19,24,25\end{array}$ & 8 \\
\hline 2. & $\begin{array}{l}\text { Harapan untuk } \\
\text { memperoleh } \\
\text { Prestasi atau } \\
\text { hasil }\end{array}$ & $\begin{array}{c}3,9,13,16 \\
21,28,29\end{array}$ & 7 \\
\hline 3. & $\begin{array}{l}\text { Keinginan } \\
\text { belajar tanpa } \\
\text { membedakan } \\
\text { tempat dan } \\
\text { waktu }\end{array}$ & 2,33 & 2 \\
\hline 4. & $\begin{array}{l}\text { Kesiapan dalam } \\
\text { menghadapi } \\
\text { kegagalan } \\
\text { dalam belajar }\end{array}$ & $\begin{array}{c}12,14,22 \\
23,26,31 \\
32\end{array}$ & 7 \\
\hline 5. & $\begin{array}{l}\text { Usaha mencari, } \\
\text { memecahkan } \\
\text { masalah }\end{array}$ & 7,10 & 2 \\
\hline 6. & $\begin{array}{l}\text { Rasa percaya } \\
\text { diri terhadap } \\
\text { kemampuan }\end{array}$ & $\begin{array}{c}5,17,18,2 \\
0,27\end{array}$ & 5 \\
\hline
\end{tabular}




\begin{tabular}{ll}
\hline sendiri dalam \\
menyelesaikan \\
tugas-tugas
\end{tabular}

Untuk menentukan tingkat kecenderungan (tinggi rendah) dari motivasi belajar digunakan rumus skor ideal (Mi) sebagai berikut:

$\mathrm{Mi}=\frac{\text { Skor tertinggi }+ \text { Skor terendah }}{2}$

Jika skor motivasi belajar lebih besar dari skor ideal ( $>\mathrm{Mi}$ ) maka motivasi belajar siswa dinyatakan cenderung tinggi, sebaliknya jika skor motivasi siswa lebih rendah dari skor ideal (< Mi) maka motivasi belajar siswa dinyatakan cenderung rendah.

\subsubsection{Tes Hasil Belajar}

Data tes hasil belajar Memahami Bahan Bangunan diperoleh melalui tes pemberian tes objektif pada siswa setelah perlakuan diberikan, dengan 4 pilihan jawaban, yaitu 1 pilihan yang benar dan 3 pilihan pengecoh. Penyusunan atau pembuatan soal untuk tes hasil belajar Memahami Bahan Bangunan diambil dari pelajaran kelas X Program Keahlian Teknik Gambar Bangunan. Setiap butir soal yang dijawab benar diberi nilai 1 dan untuk jawaban yang salah diberi nilai 0 .

Tabel 6. Kisi - Kisi Instrumen Tes Hasil Belajar Memahami bahan Bangunan

\begin{tabular}{|c|c|c|c|c|c|}
\hline \multirow{2}{*}{$\begin{array}{l}\mathbf{N} \\
\mathbf{o}\end{array}$} & \multirow{2}{*}{ Indikator } & \multicolumn{3}{|c|}{ Butir Soal } & \multirow{2}{*}{ JLH } \\
\hline & & $\mathrm{C} 1$ & $\mathrm{C} 2$ & C3 & \\
\hline 1. & $\begin{array}{l}\text { Menjelaskan } \\
\text { Jenis-Jenis } \\
\text { Kayu sebagai } \\
\text { bahan } \\
\text { bangunan }\end{array}$ & $\begin{array}{c}1,3 \\
4,5 \\
25\end{array}$ & 8,10 & $\begin{array}{c}9,22 \\
, 26\end{array}$ & 10 \\
\hline 2. & $\begin{array}{l}\text { Menjelaskan } \\
\text { sifat- sfat } \\
\text { kayu sebagai } \\
\text { bahan } \\
\text { bangunan }\end{array}$ & $\begin{array}{c}18,1 \\
9\end{array}$ & 30 & $\begin{array}{l}13,1 \\
4,21\end{array}$ & 6 \\
\hline 3. & $\begin{array}{l}\text { Menjelaskan } \\
\text { penggolonga } \\
\text { n kayu } \\
\text { sebagai } \\
\text { bahan } \\
\text { bangunan }\end{array}$ & $\begin{array}{c}7,16 \\
, 20 \\
23,2 \\
8\end{array}$ & 2,29 & $\begin{array}{c}11,1 \\
2,15 \\
, 24\end{array}$ & 11 \\
\hline
\end{tabular}

\begin{tabular}{lc}
\hline \multicolumn{1}{c}{ Jumlah } & 27 \\
\hline Keterangan: \\
C1: Pengetahuan ;C2: Pemahaman C3: Penerapan
\end{tabular}

4. Hasil Penelitian

4.1 Hasil Belajar Siswa Pada Kelas Yang Diajar Dengan Strategi Pembelajaran TPS.

Berdasarkan tes hasil belajar yang diberikan setelah proses pemberian perlakuan, skor tertinggi pada siswa yang diajar dengan menggunakan strategi pembelajaran TPS memiliki skor rata-rata 22.07, Modus 24.19, Median 24.86, standard deviasi 3.039 dan varians 9.236 dengan skor tertinggi 27; skor terendah 15 dengan jumlah sampel 30 orang. Dengan menggunakan teknik sturgess maka didapatkan rentang $=12$, banyak kelas $=5$ dan panjang interval $=2$, dan dimulai dengan batas bawah kelas pertama yaitu 15. Maka daftar distribusi frekuensi sebagai berikut.

Tabel 7. Distribusi Frekuensi Skor Hasil Belajar Yang Diajar Dengan Strategi TPS

\begin{tabular}{|c|c|c|c|}
\hline Kelas & Interval kelas & Fo & Fr $\%$ \\
\hline 1 & $15-17$ & 2 & 6.67 \\
\hline 2 & $18-20$ & 8 & 26.67 \\
\hline 3 & $21-23$ & 8 & 26.67 \\
\hline 4 & $24-26$ & 11 & 36.67 \\
\hline 5 & $27-29$ & 1 & 3.33 \\
\hline \multicolumn{2}{|c|}{ Jumlah } & 30 & 100 \\
\hline
\end{tabular}

4.2 Hasil Belajar Siswa Pada Kelas Yang Diajar Dengan Strategi Pembelajaran STAD.

Berdasarkan tes hasil belajar yang diberikan setelah proses pemberian perlakuan, skor tertinggi pada siswa yang diajar dengan menggunakan strategi pembelajaran STAD memiliki skor rata-rata 20.91, Modus 20, Median 20.75, standard deviasi 2.982 dan varians 8.894 skor tertinggi 26 skor terendah 15 dengan jumlah sampel 32 orang. Dengan menggunakan teknik sturgess maka didapatkan rentang $=11$, banyak kelas $=6$ dan panjang interval $=2$, dan dimulai dengan batas bawah kelas pertama yaitu 15. Maka daftar distribusi frekuensi sebagai berikut. 


\section{Pengaruh Strategi Pembelajaran dan Motivasi Belajar Siswa Terhadap Hasil Belajar Memahami Bahan Bagunan Pada siswa kelas X Program Keahlian Tenik Gambar Bangunan SMK Negeri 2 Medan}

Tabel 8. Distribusi Frekuensi Hasil Belajar yang Diajar dengan Strategi Pembelajaran STAD

\begin{tabular}{|c|c|c|c|}
\hline Kelas & Interval kelas & Fo & Fr $\%$ \\
\hline 1 & $15-16$ & 2 & 6.45 \\
\hline 2 & $17-18$ & 5 & 16.13 \\
\hline 3 & $19-20$ & 8 & 25.81 \\
\hline 4 & $21-22$ & 7 & 22.58 \\
\hline 5 & $23-24$ & 7 & 22.58 \\
\hline 6 & $25-26$ & 3 & 6.45 \\
\hline \multicolumn{2}{|c|}{ Jumlah } & 32 & 100 \\
\hline
\end{tabular}

4.3 Hasil Belajar Siswa Yang Memiliki Motivasi Tinggi Pada Kelas Yang Diajar Dengan Strategi Pembelajaran TPS.

Berdasarkan tes hasil belajar yang diberikan setelah proses pemberian perlakuan, skor tertinggi pada siswa yang memiliki motivasi belajar tinggi pada kelas yang diajar dengan menggunakan strategi pembelajaran TPS memiliki skor rata-rata 23.75, Modus 24.7, Median 25.16, standard deviasi 2.408 dan varians 5.8 dengan skor tertinggi $=27$; skor terendah $=19$ dengan jumlah sampel 16 orang. Dengan menggunakan teknik sturgess maka didapatkan rentang $=8$, banyak kelas $=5$ dan panjang interval $=2$. Maka daftar distribusi frekuensi sebagai berikut.

Tabel 9. Distribusi Frekuensi Hasil Belajar Siswa Yang Memiliki Motivasi Tinggi Pada Kelas Yang Diajar Dengan Strategi Pembelajaran TPS.

\begin{tabular}{cccc}
\hline Kelas & Interval kelas & Fo & Fr $\%$ \\
\hline 1 & $18-19$ & 1 & 6.250 \\
2 & $20-21$ & 2 & 12.500 \\
3 & $22-23$ & 3 & 18.750 \\
4 & $24-25$ & 6 & 37.500 \\
5 & $26-27$ & 4 & 25.000 \\
\hline \multicolumn{2}{r}{ Jumlah } & 16 & 100 \\
\hline
\end{tabular}

4.4 Hasil Belajar Siswa Yang Memiliki Motivasi Rendah Pada Kelas Yang Diajar Dengan Strategi Pembelajaran TPS.

Berdasarkan tes hasil belajar yang diberikan setelah proses pemberian perlakuan, skor tertinggi pada siswa yang memiliki motivasi belajar rendah pada kelas yang diajar dengan menggunakan strategi pembelajaran TPS memiliki skor rata-rata 20.14, Modus 23.5, Median 21.34, standard deviasi 2.59 dan varians
6.70 dengan skor tertinggi 24 skor terendah 15 dengan jumlah sampel 14 orang. Dengan menggunakan teknik sturgess maka didapatkan rentang 9 banyak kelas 4 dan panjang interval 3. Maka daftar distribusi frekuensi sebagai berikut.

Tabel 10. Distribusi Frekuensi Hasil Belajar Siswa Yang Memiliki Motivasi Rendah Pada Kelas Yang Diajar Dengan Strategi Pembelajaran TPS.

\begin{tabular}{cccc}
\hline Kelas & Interval kelas & Fo & Fr \% \\
\hline 1 & $15-17$ & 2 & 14.286 \\
2 & $18-20$ & 5 & 35.714 \\
3 & $21-23$ & 5 & 35.714 \\
4 & $24-26$ & 2 & 14.286 \\
\hline \multicolumn{2}{c}{ Jumlah } & 14 & 100 \\
\hline
\end{tabular}

4.5 Hasil Belajar Siswa Yang Memiliki Motivasi Tinggi Pada Kelas Yang Diajar Dengan Strategi Pembelajaran STAD

Berdasarkan tes hasil belajar yang diberikan setelah proses pemberian perlakuan, skor tertinggi pada siswa yang memiliki motivasi belajar tinggi pada kelas yang diajar dengan menggunakan strategi pembelajaran STAD memiliki skor rata-rata 21.29, Modus 19.7, Median 20.3, standard deviasi 2.89 dan varians 8.36 dengan skor tertinggi 26 skor terendah 16 dengan jumlah sampel 17 orang. Dengan menggunakan teknik sturgess maka didapatkan rentang 10 banyak kelas 5 dan panjang interval 2. Maka daftar distribusi frekuensi sebagai berikut.

Tabel 11. Distribusi Frekuensi Hasil Belajar Siswa Yang Memiliki Motivasi Tinggi Pada Kelas Yang Diajar Dengan Strategi Pembelajaran STAD.

\begin{tabular}{cccc}
\hline Kelas & Interval kelas & Fo & Fr $\%$ \\
\hline 1 & $15-16$ & 1 & 5.88 \\
2 & $17-18$ & 2 & 11.76 \\
3 & $19-20$ & 5 & 29.41 \\
4 & $21-22$ & 3 & 17.65 \\
5 & $23-24$ & 4 & 23.53 \\
6 & $25-26$ & 2 & 11.76 \\
\hline \multicolumn{2}{c}{ Jumlah } & 17 & 100 \\
\hline
\end{tabular}


4.6 Hasil Belajar Siswa Yang Memiliki Motivasi Rendah Pada Kelas Yang Diajar Dengan Strategi Pembelajaran STAD

Berdasarkan tes hasil belajar yang diberikan setelah proses pemberian perlakuan, skor tertinggi pada siswa yang memiliki motivasi belajar rendah pada kelas yang diajar dengan menggunakan strategi pembelajaran STAD memiliki skor rata-rata 20.20, Modus 20.5, Median 22.25, standard deviasi 2.157 dan varians 4.653 dengan skor tertinggi 24 skor terendah 15 dengan jumlah sampel 15 orang. Dengan menggunakan teknik sturgess maka didapatkan rentang 9 banyak kelas 5 dan panjang interval 2. Maka daftar distribusi frekuensi sebagai berikut.

Tabel 12. Distribusi Frekuensi Hasil Belajar Siswa Yang Memiliki Motivasi Rendah Pada Kelas Yang Diajar Dengan Strategi Pembelajaran STAD

\begin{tabular}{|c|c|c|c|}
\hline Kelas & Interval kelas & Fo & Fr $\%$ \\
\hline 1 & $15-16$ & 1 & 6.67 \\
\hline 2 & $17-18$ & 3 & 20.00 \\
\hline 3 & $19-20$ & 4 & 26.67 \\
\hline 4 & $21-22$ & 4 & 26.67 \\
\hline 5 & $23-24$ & 3 & 20.00 \\
\hline \multicolumn{2}{|r|}{ Jumlah } & 15 & 100 \\
\hline
\end{tabular}

\section{Pembahasan Hasil Penelitian}

5.1 Pengaruh Strategi Pembelajaran TPS dan Strategi Pembelajaran STAD Terhadap Hasil Belajar Memahami Bahan Bangunan

Berdasarkan penelitian menunjukkan bahwa strategi pembelajaran memberikan pengaruh yang berbeda secara signifikan terhadap hasil belajar. Selanjutnya dari hasil tersebut bahwa strategi pembelajaran TPS terbukti lebih tinggi dalam meningkatkan hasil belajar siswa dibandingkan dengan strategi pembelajaran STAD. Hal ini kemungkinan karena dalam pembelajaran dengan pembelajaran TPS, siswa akan lebih aktif dan akan bekerja saling membantu, dan saling bertukar pendapat atau pemikiran antara yang satu dengan yang lain tentang pembelajaran yang diterima. Dalam pembelajaran TPS, pada materi pelajaran yang dipelajari dikaitkan dengan situasi dunia nyata siswa agar memudahkan mereka dalam menanggapi dan memahami pengetahuan, bahkan membuat anak didik mudah memusatkan perhatian, sehingga materi pelajaran yang akan dipelajari akan lebih berarti jika siswa mempelajari materi pelajaran yang disajikan melalui lingkungan sekitar.

Dari penelitian ini dapat disimpulkan bahwa strategi pembelajaran TPS memberi pengaruh yang lebih baik terhadap hasil belajar siswa dibandingkan dengan strategi pembelajaran STAD.

\subsection{Pengaruh Motivasi Belajar Tinggi Rendah Terhadap Hasil Belajar Memahami Bahan Bangunan}

Berdasarkan penelitian menunjukkan bahwa motivasi belajar memberikan pengaruh terhadap hasil belajar. Dari rata-rata hasil belajar siswa diperoleh bahwa rata-rata hasil belajar siswa yang memiliki motivasi belajar tinggi lebih baik dari pada rata-rata hasil belajar yang memiliki motivasi yang rendah. Selanjutnya dari hasil tersebut nyata bahwa motivasi belajar terbukti memiliki pengaruh yang berbeda secara signifikan dalam meningkatkan hasil belajar siswa.

Dari penelitian ini, dapat disimpulkan berdasarkan pengujian hipotesis kedua terbukti bahwa motivasi belajar siswa yang tinggi memberikan pengaruh yang lebih baik dan dapat meningkatkan hasil belajar siswa dibandingkan dengan siswa yang memiliki motivasi belajar rendah.

5.3 Interaksi Antara Strategi Pembelajaran TPS dan Strategi Pembelajaran STAD dengan Motivasi Belajar Siswa Terhadap Hasil Belajar.

Berdasarkan penelitian menunjukkan bahwa terdapat interaksi antara strategi pembelajaran dan motivasi belajar terhadap hasil belajar memahami bahan bangunan. Siswa yang memiliki motivasi belajar tinggi dengan menggunakan strategi pembelajaran TPS lebih tinggi hasil belajarnya dibandingkan dengan siswa yang memiliki motivasi tinggi yang diajar dengan strategi pembelajaran STAD, sementara siswa yang memiliki motivasi rendah yang diajar dengan strategi pembelajaran STAD lebih tinggi, dibandingkan hasil belajar siswa yang memiliki motivasi belajar rendah yang diajar dengan strategi TPS. Hal ini menunjukkan adanya interaksi antara strategi pembelajaran dengan motivasi belajar terhadap hasil belajar. 


\section{Pengaruh Strategi Pembelajaran dan Motivasi Belajar Siswa Terhadap Hasil Belajar Memahami Bahan Bagunan Pada siswa kelas X Program Keahlian Tenik Gambar Bangunan SMK Negeri 2 Medan}

Meksipun strategi pembelajaran TPS baik digunakan pada siswa yang memiliki motivasi tinggi, namun tidak tertutup kemungkinan strategi pembelajaran TPS ini juga dapat digunakan pada siswa yang memiliki motivasi rendah. Hal ini dikarenakan strategi pembelajaran TPS akan melatih siswa untuk bekerja sama dan saling berbagi pengetahuan sehingga mampu memotivasi siswa agar dapat memahami materi bahan bangunan melalui lingkungan sekitar mereka.

\section{Kesimpulan, Implikasi dan Saran}

\subsection{Kesimpulan}

Berdasarkan hasil penelitian, maka kesimpulan yang dapat yaitu sebagai berikut:

a. Hasil belajar siswa pada pelajaran Memahami Bahan Bangunan yang diajar dengan strategi pembelajaran TPS $\bar{X}=22,07$ lebih tinggi dari pada nilai rata-rata hasil belajar siswa yang diajar dengan strategi pembelajaran STAD $\bar{X}=20.91$. pada data hasil penelitian kelas $X$ program keahlian Teknik Gambar Bangunan SMK N 2 Medan Tahun Ajaran 2014/2015.

b. Hasil belajar siswa pada pelajaran Memahami Bahan Bangunan yang memiliki motivasi belajar tinggi menunjukkan bahwa hasil belajarnya juga tinggi dibanding pada siswa yang memiliki motivasi rendah. Hal ini juga terlihat pada motivasi belajar tinggi dengan rata-rata $\bar{X} 23.75$ lebih tinggi dari hasil belajar siswa yang memiliki motivasi belajar rendah $\bar{X} 20.14$ pada siswa kelas $X$ program keahlian Teknik Gambar Bangunan SMK N 2 Medan Tahun Ajaran 2014/2015.

c. Terdapat interaksi antara strategi pembelajaran dan motivasi belajar terhadap hasil belajar hal ini terlihat juga pada ratarata hasil belajar siswa dimana untuk motivasi tinggi STAD dengan $\bar{X}_{\mathrm{STAD}}=21.29$ lebih tinggi dari rata-rata hasil belajar motivasi rendah $\bar{X}_{\mathrm{STAD}}=20.20$ dan rata-rata hasil belajar untuk motivasi tinggi dengan $\bar{X}_{\text {TPS }}=23.75$ lebih tinggi dari rata-rata hasil belajar motivasi rendah $\bar{X}_{\mathrm{TPS}}=20.14$ untuk pelajaran memahami bahan bangunan pada siswa kelas $\mathrm{X}$ program keahlian Teknik Gambar Bangunan SMK N 2 Medan Tahun Ajaran 2014/2015.

d. Tidak ada strategi yang digunakan yang cocok untuk suatu kondisi dalam motivasi belajar siswa.

\subsection{Implikasi}

Bedasarkan kesimpulan pertama yang menyatakan bahwa strategi pembelajaran TPS lebih baik dibandingkan dengan strategi pembelajaran STAD. Strategi pembelajaran TPS lebih memotivasi siswa untuk dapat menguasai materi pembelajaran.

Hasil simpulan kedua, yang menyatakan bahwa hasil belajar siswa yang memiliki motivasi tinggi lebih baik dari pada siswa yang memiliki motivasi rendah.

Hasil simpulan ketiga, yang menyatakan adanya interaksi antara strategi pembelajaran dan motivasi belajar terhadap hasil belajar siawa, dimana hasil belajar siswa yang memiliki motivasi tinggi yang diajar dengan TPS lebih baik dari siswa yng memiliki motivasi tinggi bagi siswa yang diajar dengan strategi STAD, dan hasil belajar siswa yang memiliki motivasi rendah yang diajar dengan strategi STAD lebih tinggi dari siswa yang memiliki motivasi rendah dan diajar strategi pembelajaran TPS. Oleh karenanya perlu ada kesesuaian antara strategi pembelajaran dengan karakteristik yang dimiliki siswa serta perlunya peran guru untuk mendorong dan menumbuhkan motivasi belajar siswa, sehingga siswa lebih giat dan sungguhsungguh dalam belajar untuk memperoleh hasil yang lebih baik dari hasil belajar yang sudah diperoleh sebelunya.

\subsection{Saran}

Berdasarkan hasil analisis data dan kesimpulan yang dikemukakan sebelumnya, maka disarankan hal-hal sebagai berikut:

a. Agar setiap guru pengajar harus memahami karakteristik dari pada peserta didiknya untuk dapat memilih strategi pembelajaran yang lebih tepat sehingga dapat mewujudkan tujuan pembelajaran yang telah ditetapkan

b. Agar setiap guru pengajar mengenal, memahami dan dapat mengaplikasikan sejumlah strategi pembelajaran sehingga mereka dapat memilih strategi pembelajaran yang lebih efektif untuk pembelajaran tertentu

c. Selain dari pada itu, guru juga harus turut memperhatikan faktor internal dari siswa dalam setiap proses pembelajaran, salah satunya adalah motivasi belajar siswa.

d. Perlu dilakukan penelitian lanjut guna meningkatkan kajian tentang berbagai 
strategi pembelajaran untuk meningkatkan hasil belajar siswa.

\section{Daftar Pustaka}

Agus Suprijono. 2009. Cooperatif Learning Teori $\mathcal{E}$ Aplikasi PAIKEM. Surabaya: Pustaka Belajar

Arikunto Suharsimi. 2005. Dasar-dasar Evaluasi Pendidikan (Edisi Revisi). Jakarta: Bumi Aksara.

Arikunto Suharsimi. 2010. Prosedur Penelitian (Edisi Revisi). Jakarta: Rineka Cipta

Arikunto Suharsimi. 2000. Manajemen Penelitian. Jakarta: Rineka Cipta

Effendi Yogi, 2011 Perbedaan Hasil Belajar Yang Diajar Dengan Model Pembelajaran Kooperatif Tipe STAD dan TPS Pada Standar Kopetensi Menggunakan AlatAlat Ukur Kelas X SMK N 2 Tebing Tinggi T.A 2011/2012".

Hamzah B, Uno.2011. Perencanaan Pembelajaran. Jakarta : Bumi Aksara

Lie, A., 2002. Cooperatif Learning. Jakarta: Grasindo

Marbun Tulus, 2010. Pengaruh Strategi Pembelajaran Dan Motivasi Belajar Terhadap Hasil Belajar Teori Dasar Elektonika Siswa SMK 1 Percut Sei Tuan 2010/2011

Hasibuan Muhammad Anasri, 2010 Pengaruh Strategi

Kooperatif Tipe

Terhadap Hasil Pembelajaran

Bangunan Pad

Siswa Kelas X SMK Negeri 1 Percut Sei Tuan Tahun Pembelajaran 2010/2011.

Husaini, Purnomo. 2008. Pengantar statistic. Jakarta: Bumi Aksara

Purwanto, Ade. 1996. Psikologi Pembelajaran. Jakarta: PT Rineka Cipta

Purwanto, Ade. 2007. Strategi Pembelajaran. Jakarta . PT Rineka Cipta.

Saragih Kisastro, 2012 Pengaruh Penerapan Model Pembelajaran Kooferatif STAD (Student Teams Achivement Division) Terhadap Hasil Belajar Memahami Dasar Kekuatan Bahan dan Komponen Mesin Pada Siswa Kelas X Program Studi Keahlian Teknik Mesin SMK Negeri 1 Percut Sei Tuan TA. 2012/2013

Sanjaya, Wina. 2006. Strategi Pembelajaran. Bandung: Prenada Media Group.
Sardiman, A. M. 2008. Intraksi \& Motivasi Belajar Mengajar. Jakarta : PT. Raja Grafindo Persada.

Sardiman, A. M. 2011. Intraksi \& Motivasi Belajar Mengajar. Jakarta : PT. Raja Grafindo Persada.

Selameto. 2003. Belajar Dan Faktor-Faktor Yang Mempengaruhinya. Jakarta: Rineka Cipta

Simanjuntak, Rihold, R. 2013. Pengaruh Media Pembelajaran Dan Motivasi Belajar Siswa Terhadap Hasil Belajar Pengetahuan Menggambar Teknik Dasar Pada Siswa Kelas X Program Keahlian Teknik Gambar Bangunan Smk Negeri 1 Lubuk Pakam Tahun Ajaran 2012 /201. skripsi FT UNIMED

Siregar, Jese. 2010. Pengaruh Model Pembelajaran Dan Motivasi Belajar Terhadap Hasil Belajar Teori Dasar Elektronika Pda Siswa Kelas I Program Keahlian Teknik Audio Video SMK Negeri 1 Percut Sei Tuan T.A 2009/2010, skripsi FT UNIMED

Sudjana, Nana. 2005, Metode Statistika, Tarsito, Bandung.

Sudjana, Nana. 2008. Kurikulum Dan Pembelajaran. Jakarta: PT. Bumi Aksara

Trianto. 2009. Mendesain Model Pembelajaran Inovatif-Progresif: Konsep Landasan dan Implementasi Pada Kurikulum Tingkat Satuan Pendidikan (KTSP). Jakarta: Kencan. 